\title{
Respiratory impairment in coffee factory workers in the Asaro Valley of Papua New Guinea
}

\author{
D SMITH, KAREN BROTT, AND G KOKI \\ From the Papua New Guinea Institute of Medical Research, Goroka, EHP, Papua New Guinea
}

ABSTRACT In a coffee growing area of Papua New Guinea, a developing country in the western Pacific region, coffee factory workers were found to have more chronic symptomatic respiratory impairment than a carefully matched group of neighbouring villagers. This impairment was not related to their duration of employment. Coffee factory workers were found also to have a greater prevalence of reversible but asymptomatic airways obstruction on entering their factories after two days off duty than a group of soft drink factory workers. These findings are thought to be related to exposure to the dust produced in large quantities during coffee processing.

The health problems associated with occupation among workers in the world's developing (and generally tropical) countries have been largely ignored. ${ }^{\prime}$ Nevertheless, such countries produce and process many economically important commodities, notable among which is coffee.

Coffee is Papua New Guinea's major export crop. In 1979 nearly 50000 tonnes with a value of $\mathrm{K} 125 \mathrm{~m}(£ 83.3 \mathrm{~m})$ were exported. This represented $38 \%$ of all primary production exports. About one third of the country's population is estimated to be directly concerned in producing coffee, either as small holder growers or as employees on large plantations. An estimated 750 people are permanently employed in coffee processing factories in the highlands, almost $10 \%$ of these in the Asaro Valley of the Eastern Highlands Province, a relatively remote and socioeconomically undeveloped area.

Before receipt at a factory the coffee beans (seeds) have been removed from the cherries (fruit) and dried in the sun. No dust is produced during these processes. In the factory four processes are carried out. The parchment skin around the beans is first removed by a machine called a huller/polisher that also polishes off the tight silver skin surrounding the beans. The coffee is then referred to as "green beans." These beans are then graded for size (broken or discoloured beans being discarded) and bagged. Most coffee is exported at this stage. In the Asaro Valley one factory also roasts green beans. The considerable quantities of dust produced during hulling and polishing settles on all surfaces through-

Received 20 August 1984

Accepted 15 October 1984 out the factory and is resuspended during grading and bagging operations.

The present paper reports studies of the respiratory function and dust exposure of 69 male workers in 11 factories in the Asaro Valley. There have been many published accounts of allergy to coffee beans in those occupationally exposed. Asthma, ${ }^{2-4}$ extrinsic allergic alveolitis, ${ }^{5}$ dermatitis, ${ }^{6}$ oedema, ${ }^{3}$ and rhinitis and lacrimation ${ }^{35}$ have all been described. There has also been one report of chronic bronchitis occupationally associated with exposure to coffee factory dust. ${ }^{7}$

\section{Methods}

Sixty nine men permanently employed in the 11 coffee factories in the Asaro Valley were identified and matched for age, height, ethnic origin, and smoking habit with 69 men drawn at random from the Asaro Valley village census books. Twenty two permanent male employees of a soft drink factory in urban Goroka were identified.

The respiratory function of all 69 coffee factory workers was assessed on two occasions four months apart. On each occasion forced expiratory spirograms were obtained using a Vitalograph spirometer with the subject standing and without the use of a nose clip. The forced expiratory manoeuvre was repeated until a reproducible trace was obtained. It was not considered necessary to correct readings to BTPS since the weather in the Asaro Valley is consistently warm. All subjects and controls were questioned about their smoking habits, place of birth, employment history, and housing.

A random subsample of 31 of the coffee factory 
workers and all 22 of the soft drink factory workers also had forced expiratory spirograms performed at the start and end of their first shift of work after two days off duty.

Gravimetric assays of dust levels were made in one coffee factory using a Sartorius MB2 air sampler with $5.0 \mu$ Millipore SM filters. Assays were made on 11 different days over a six week period when the level of activity in the factory varied considerably from day to day depending principally on the quantity of coffee beans available for processing.

An aqueous extract of coffee bean husk, prepared by the clinical immunology unit, Princess Margaret Hospital, Perth, Western Australia, was used to test for skin hypersensitivity in the coffee factory workers with chronic non-specific lung disease (CNSLD) and in 12 workers without CNSLD. Coca's solution was used as a control, and the skin of the flexor surface of the forearm was used in the manner described by Dowse. ${ }^{8}$

\section{Results}

\section{GENERAL}

Village controls did not differ as a group from the coffee factory workers in age, height, smoking habit, or housing. The soft drink factory workers differed from the coffee factory workers only in that they mostly lived in low cost urban housing and that they were slightly younger (table).

\section{LUNG FUNCTION}

Six $(8.7 \%)$ of the 69 coffee factory workers but only one $(1.5 \%)$ of the 69 controls had a chronic productive cough and a forced vital capacity of less than $80 \%$ of that predicted for his age and height. This difference in prevalence is statistically significant $(p=0.05$, Chi square). Clinical and radiological examination showed that all seven were suffering from CNSLD.

There was no significant difference in the mean forced expiratory volume/forced vital capacity ratio or between mean forced vital capacities of factory

Table Cross shift changes in lung function in soft drink factory workers and in a subgroup of the coffee factory workers

\begin{tabular}{|c|c|c|}
\hline & $\begin{array}{l}\text { Coffee factory } \\
\text { workers }\end{array}$ & $\begin{array}{l}\text { Soft drink factory } \\
\text { workers }\end{array}$ \\
\hline $\begin{array}{l}\text { No examined } \\
\text { Mean age (SD) } \\
\text { Mean FEV (1) at start } \\
\text { of shift (SD) }\end{array}$ & $\begin{array}{l}31 \\
32(9) \\
2.7(0 \cdot 8)\end{array}$ & $\begin{array}{l}22 \\
27(8) \\
3.3(0.5)\end{array}$ \\
\hline $\begin{array}{l}\text { Mean FEV (I) at end } \\
\text { of shift (SD) }\end{array}$ & $2.7(0.7)$ & $3.3(0.6)$ \\
\hline $\begin{array}{l}\text { No of workers with an FEV } \\
\text { drop of }>10 \%\end{array}$ & $6(19 \%)$ & $1(4 \%)$ \\
\hline
\end{tabular}

workers and of controls who did not have CNSLD. There was no correlation between forced vital $\stackrel{\varnothing}{\varrho}$ capacity (as percentage of that predicted for age and height) and duration of exposure to coffee factory $\stackrel{5}{+}$ dust among the factory workers. Exposure ranged from less than one year to 20 years, with a median of six years.

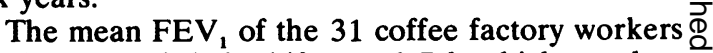
at the start of their shift was 2.71 , which was less than that of the soft drink factory workers, $3.31 \mathrm{c}$ (table 1). The mean FEV $V_{1}$ of both groups of workers $\vec{\circ}$ remained unchanged by the end of their workshifts, $\overrightarrow{\vec{\omega}}$ but six $(19 \%)$ of the 31 coffee workers and one ${ }_{\sigma}$ (4\%) of the 22 soft drink workers suffered a drop in $\mathrm{FEV}_{1}$ of more than $10 \%$.

The test/retest correlation between the spirometric measures made four months apart was high. In the six coffee factory workers with CNSLD is for $\mathrm{FEV}_{1} \mathrm{r}=0.99$ and for $\mathrm{FVC} \mathrm{r}=0.93$.

No factory worker complained of impaired 음 respiratory function associated with entering the fac- $\rightarrow$ tory, but nine $(13 \%)$ coffee workers complained of itchy skin while in the factory, and five (7\%) complained of sore eyes or nasal discharge, or both, $\overrightarrow{0}$ which they associated with exposure to the factory of atmosphere. No factory worker other than the six diagnosed as having CNSLD had a chronic productive cough.

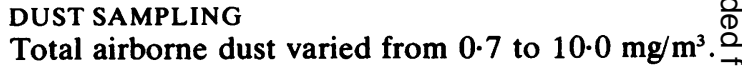
Most of this day to day difference is accounted for $\overline{\vec{D}}$ by differing levels of large particles - that is, particles that could be easily shaken off the Millipore filter and that were about $5 \mu$ or more in diameter (fig 1).

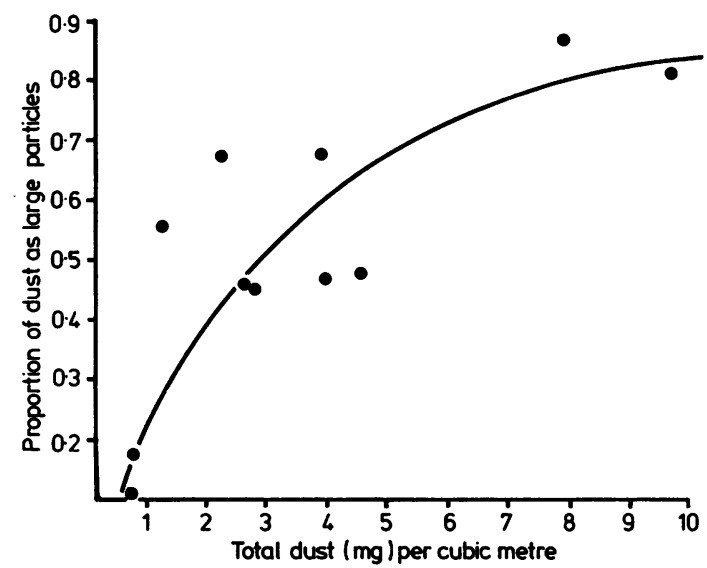

Fig 1 Relation between total dust and proportion of large particles $(\geqslant 5 \mu)$. 


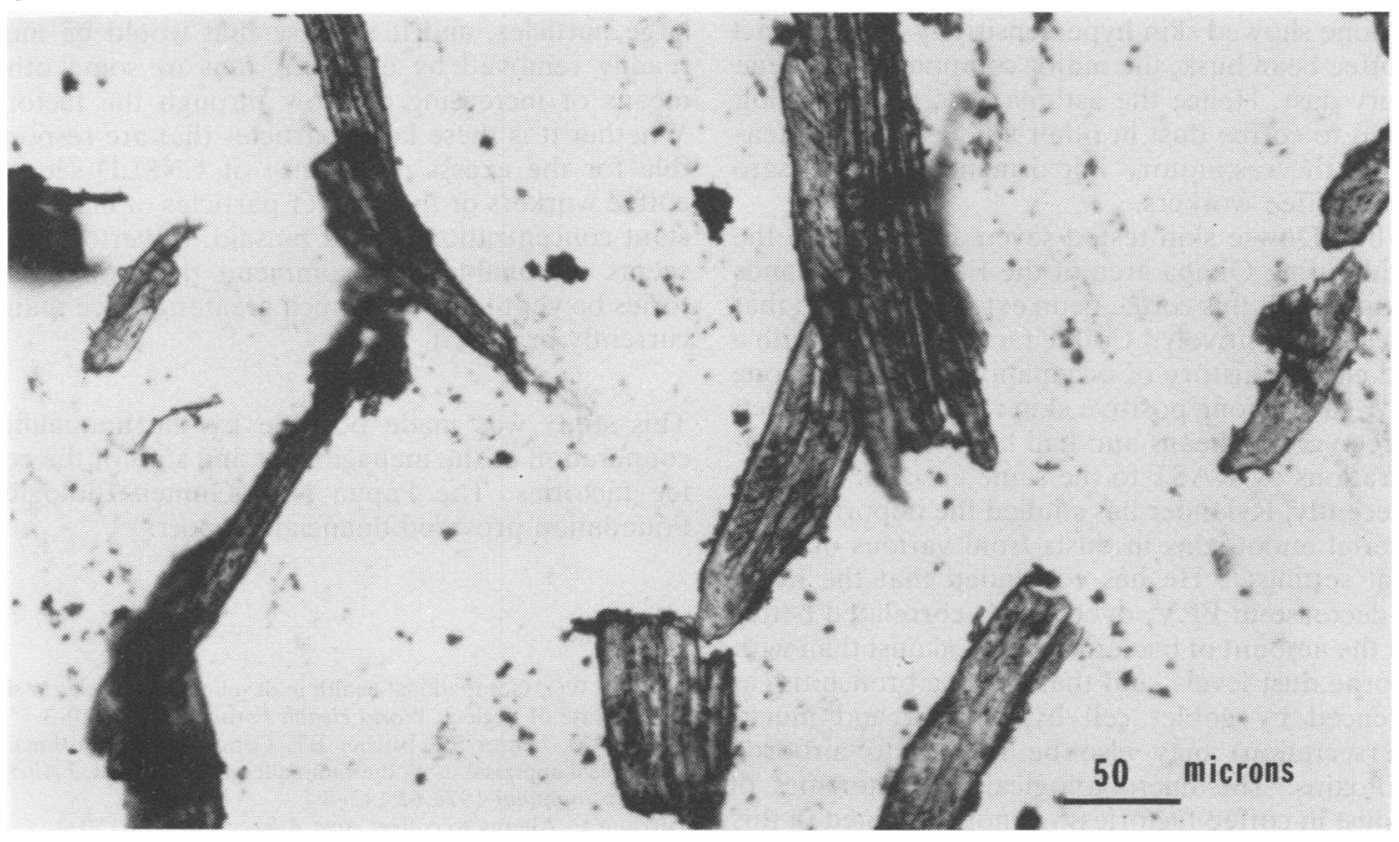

Fig 2 Photomicrograph of sample of dust filtered from the air of a coffee factory. Larger particles at least are segments of coffee bean husk.

Figure 2 shows a photomicrograph of a sample of dust so collected. Many particles are identifiable: fragments of coffee bean husk, being cigar shaped and measuring about $300 \times 40 \mu$. Some are filamentous, measuring around $800 \times 20 \mu$ whereas others are roughly circular and of diameter between $20 \mu$ and $200 \mu$. There are also many small circular particles of diameter around $5 \mu$ whose origin is less clear.

Hence it seems that there is a baseline level of factory air dust in the order of $1.0 \mathrm{mg} / \mathrm{m}^{3}$ or less, comprised of small circular particles of approximate diameter $5 \mu$ whose origin is not clear. With increasing factory activity, such as the operation of husking machines or sorting machines or the filling of sacks, dust levels rise to up to 10 times this basic level, and $40-85 \%$ of this dust is comprised of large particles. Most of these measure at least $50 \mu$ along their shortest axis.

\section{SKIN TESTING}

None of the six coffee workers with CNSLD nor the 12 coffee workers without CNSLD showed skin hypersensitivity to the coffee bean husk extract.

\section{Discussion}

CNSLD is a common condition of obscure aetiology affecting adults in Papua New Guinea. It is charac- terised by chronic productive cough and irreversible obstructive ventilatory defect. It differs from the chronic obstructive lung disease seen in industrialised societies in that there is an equal sex distribution, a late onset of dyspnoea, and a lack of appreciable lung overinflation." The present study has shown that whereas this condition is considerably more prevalent in coffee factory workers than in matched controls it is not an inevitable consequence of exposure to coffee factory dust. It seems reasonable to assume that the development of CNSLD in susceptible subjects is accelerated or precipitated by such exposure. There is no dose response relationship between exposure to coffee factory dust and impaired lung function.

The difference between the mean $\mathrm{FEV}_{1}$ of the coffee factory workers tested cross-shift and that of the soft drink factory workers is too great to be explained by the five year difference in the mean age of these groups and may be related to dust exposure. More individual coffee factory workers than soft drink factory workers suffered a reversible FEV $_{1}$ drop of more than $10 \%$, but this difference between the two groups was not statistically significant $(\mathrm{p}=$ $0 \cdot 1$, Fisher's exact test).

Despite the fact that one in five coffee factory workers suffered a slight but functionally significant reversible drop in lung function over the course of a working shift, none had recognised this subjectively, 
and none showed skin hypersensitivity to an extract of coffee bean husk, the major component of coffee factory dust. Hence the asthma described as being related to coffee dust in other studies ${ }^{2}$ is not a feature of the respiratory impairment seen in Asaro Valley coffee workers.

When Dowse skin tested seven asthmatics in the neighbouring Okapa area of the Eastern Highlands Province with this coffee bean extract, he found that six reacted positively. ${ }^{8}$ Coffee factory workers with a good clinical history of occupational asthma in one study $^{2}$ gave strong positive skin reactions to extracts of green coffee beans and had high serum IgE concentrations by RAST to the same antigen.

Recently, Rylander has studied the importance of bacterial endotoxins in dusts from various occupational settings. ${ }^{10} \mathrm{He}$ has concluded that the average decrease in $\mathrm{FEV}_{1}$ over a shift correlated better with the amount of bacteria on cotton dust than with airborne dust levels, and that chronic bronchitis (as evidenced by goblet cell hyperplasia and mucus hypersecretion) may also be related to airborne endotoxins. The microbiological characteristics of the dust in coffee factories was not examined in this study.

A programme of worker surveillance should be instituted immediately, with the aim of the early removal from exposure to dust of any worker who develops symptoms or signs of CNSLD. A worker who suffers reversible (albeit asymptomatic) drop in lung function on acute exposure to factory dust should be considered at risk and tested more frequently. A reduction of ventilatory capacity exceeding $10 \%$ of the preshift value is regarded by the National Institute for Occupational Safety and Health in the United States as a "definite and marked effect of dust." "1

It is not possible to define a "safe" level of dust in factory air. We have shown that much of the day to day variation in dust levels is made up of relatively large particles, and it is these that would be most readily removed by extractor fans or some other $\stackrel{\mathbb{Q}}{\stackrel{2}{ }}$ means of increasing air flow through the factory. Whether it is these large particles that are responsible for the excess prevalence of CNSLD seen in coffee workers or the smaller particles of more constant concentration cannot be said. Nevertheless, it $\frac{\bar{s}}{T}$ seems reasonable to recommend that coffee fac- $\stackrel{\mathbb{Q}}{\varrho}$ tories be ventilated to a much greater degree than is currently practised.

This study was made possible by the unqualified $\overrightarrow{\vec{\omega}}$ cooperation of the management and staff of the cof- $\frac{\Omega}{\circ}$ fee factories. The Papua New Guinea Biological Foundation provided financial support.

\section{References}

' Phoon WO. Occupational health in developing countries: a sim- 음 ple case of neglect. World Health Forum 1983;4:340-3.

${ }^{2}$ Karr RM, Lehrer SB, Bitcher BT. Coffee workers' asthma: a c clinical appraisal using the radio allergosorbent test. J Allergy Clin Immunol 1978;62:143-8.

${ }^{3}$ Bruun E. Allergy to coffee. Acta Allergy 1975;11:150-4.

4 Karr RM, Davies RJ, Butcher BT, et al. Occupational asthma. $J$ or Allergy Clin Immunol 1978;61:54-65.

${ }^{5}$ Van Toorn DW. Coffee workers' lung: a new example of extrinsic allergic alveolitis. Thorax 1970;25:399-405.

- Kaye M, Freedman SO. Allergy to raw coffee-an occupational disease. Can Med Assn J 1961;18:469-71.

' Zuskin E, Valic F, Skurie Z. Respiratory function in coffee workers. Br J Ind Med 1979;36:117-22.

${ }^{8}$ Dowse G. Asthma in village communities of the Papua New Guinea Highlands. University of Western Australia, 1981. (BSc med thesis.)

- Woolcock AJ, Blackburn CRB, Freeman MH, Zylstra W, Spring SR. Studies of chronic (non-tuberculous) lung disease in New Guinea populations: the nature of the disease. Am Rev Respir Dis 1970;102:575-90.

${ }^{10}$ Rylander R, Snella MC. Endotoxins and the lung: cellular reactions and risk for disease. Prog Allergy 1983;33:332-44.

" National Institute for Occupational Safety and Health. Occupational exposure to cotton dust. Criteria for a recommended standard. Washington: NIOSH 1974. (HEW publication.) 